\title{
PROSES PEMBENTUKAN PERDA MENGENAI DESA ADAT DI KABUPATEN SERAM BAGIAN BARAT PROVINSI MALUKU
}

\author{
Oleh \\ Muh. Rival Payapo ${ }^{1}$, \\ Muchlis Hamdi' ${ }^{2}$, Megandaru Widhi Kawuryan ${ }^{3}$ \\ 1) Sekretariat Daerah Kabupaten Seram Bagian Barat \\ Program Magister Terapan Studi Pemerintahan Institut Pemerintahan Dalam Negeri \\ rival.payapo19@gmail.com \\ ${ }^{2,3)}$ Institut Pemerintahan Dalam Negeri
}

\begin{abstract}
$T$ is research was motivated interested the author's discuss the integrated one-stop service effectiveness in improving the quality of public services in the office PTSP of South Jakarta Administration City DKI Jakarta Province because based on data shows that in the implementation of the one stop service, city administration of South Jakarta have low receiving an application license and non license when compared to any other municipality with a population less. In addition to other obstacles that hinder the quality of service in the implementation of the one stop sevice that was limited human resources that serve as front office to serve the public every day, and facilities doesn't adequate to support the implementation of a quality sevice.

The birth of Law Number 6 of 2014 concerning Villages provides opportunities for villages in Indonesia to improve the welfare and independence of villages in accordance with prevailing customs. This opportunity was welcomed by the Government of Seram Bagian Barat by forming a regional regulation on indigenous villages to manage administration of indigenous village governance in the Seram Bagian Barat, although the process of its formation from 2017 to 2019 cannot yet be established.
\end{abstract}

This study aims to analyze the process of forming regional regulations on indigenous villages in Seram Bagian Barat using Indrati's theory (2017), factors affecting that use Halim's theory (2013), and strategies for effectiveness the process of forming regional regulations about indigenous villages using SWOT analysis. The research method used is qualitative research by parsing the data descriptively. Technique of collecting data is done by interview, observation, and documentation by using analysis technique of data reduction, data display, and conclusion.

The results of this study indicate that the process of forming regional regulations on indigenous villages in the Seram Bagian Barat has not been implemented in accordance with the theory and provisions of legislation, which resulted in the designation of local regulations in Seram Bagian Barat not yet being established and passed into regional regulations. factors such as the lack of quality of the DPRD in implementing the legislative function, the interests of various parties, the lack of supporting staf quality, the slow setting of Indigenous villages by the Local Government and the lack of involvement of community participation, especially the involvement of traditional institutions in Seram Bagian Barat. Strategy to formation of regional regulations effective about Indigenous villages is to establish good communication between the DPRD and the Regional Government in formation regional regulations regarding Indigenous villages in accordance with 
the provisions of legislation, involving community participation, especially traditional institutions in preparing draft regional regulations, and minimizing interests that are not in accordance with regulations and traditional rules in Seram Bagian Barat.

Keywords: forming, design, regional regulation, Indigenous village

\section{AbSTrak}

$\mathrm{L}$ ahirnya Undang-Undang No. 6 Tahun 2014 tentang Desa memberikan peluang kepada desa di Indonesia untuk meningkatkan kesejahteraan dan kemandirian desa sesuai dengan adat istiadat atau kebiasaan yang berlaku. Peluang ini disambut baik oleh Pemerintah Kabupaten Seram Bagian Barat dengan membentuk peraturan daerah mengenai desa adat guna mangatur jalannya penyelenggaraan pemerintahan desa adat di Kabupaten Seram Bagian Barat, walaupun dalam proses pembentukannya dari tahun 2017 sampai dengan tahun 2019 belum dapat ditetapkan.

Penelitian ini bertujuan untuk menganalisis proses pembentukan peraturan daerah mengenai desa adat di Kabupaten Seram Bagian Barat menggunakan teori Indrati (2017), faktorfaktor yang memengaruhi menggunakan teori Halim (2013), dan Strategi dalam mengefektifkan proses pembentukan peraturan daerah mengenai desa adat menggunakan analisis SWOT. Metode penelitian yang digunakan adalah penelitian kualitatif dengan menyajikan data secara deskriptif. Teknik pengumpulan data dilakukan dengan wawancara, observasi, serta dokumentasi dengan menggunakan teknik analisis reduksi data, display data, dan penarikan Simpulan.

Hasil penelitian ini menunjukkan bahwa Proses pembentukan peraturan daerah mengenai desa adat di Kabupaten Seram Bagian Barat belum dilaksanakan sesuai dengan teori dan ketentuan peraturan perundang-undangan, yang mengakibatkan rancangan peraturan daerah mengenai desa adat di Kabupaten Seram Bagian Barat belum dapat ditetapkan dan disahkan menjadi peraturan daerah. Faktor-faktor yang memengaruhi, yaitu kurangnya kualitas DPRD dalam melaksanakan fungsi legislasi, adanya kepentingan berbagai pihak, kurangnya kualitas SDM tenaga pendukung, lambatnya penetapan desa adat oleh Pemerintah Daerah dan kurangnya pelibatan partisipasi masyarakat khususnya pelibatan lembaga adat di Kabupaten Seram Bagian Barat. Strategi dalam mengefektifkan pembentukan peraturan daerah mengenai desa adat, yaitu membangun komunikasi yang baik antara DPRD dan Pemerintah Daerah dalam membentuk peraturan daerah mengenai desa adat sesuai dengan ketentuan peraturan perundang-undangan, melibatkan partisipasi masyarakat khususnya lembaga adat dalam menyiapkan rancangan peraturan daerah, dan meminimalisir kepentingan yang bertentangan dengan aturan normatif dan aturan adat di Kabupaten Seram Bagian Barat.

Kata kunci: pembentukan, rancangan, peraturan daerah, desa adat

\section{PENDAHULUAN}

$\mathrm{T}^{2}$ juan utama penyelenggaraan pemerintahan Negara Indonesia, yaitu menyejahterakan bangsa Indonesia, seperti yang termuat dalam Pembukaan Undang-Undang Dasar Negara Republik Indonesia yang menjelaskan tujuan penyelenggaraan pemerintahan Indonesia adalah "untuk membentuk suatu pemerintahan negara Indonesia yang melindungi segenap bangsa Indonesia dan seluruh tumpah darah
Indonesia dan untuk memajukan kesejahteraan umum, mencerdaskan kehidupan bangsa dan ikut melaksanakan ketertiban dunia yang berdasarkan kemerdekaan perdamaian abadi dan keadilan sosial" .

Dalam mewujudkan kesejahteraan rakyat yang merupakan tujuan penyelenggaraan pemerintahan Negara Indonesia, diperlukan pengaturan agartujuan yang ingin dicapai berjalan sesuai harapan, sehingga pemerintah mengeluarkan produk- 
produk hukum atau kebijakan baik di tingkat nasional, provinsi, kabupaten/kota bahkan sampai ke tingkat desa. Hal tersebut sejalan dengan pendapat Indrati (2017: 1) yang mengatakan:

"Dengan diembannya tugas negara dalam menyelenggarakan kesejahteraan umum, maka pembentukan berbagai peraturan di Negara Republik Indonesia ini menjadi sangat penting, Oleh karena itu, campur tangan negara dalam mengurusi kesejahteraan rakyat dalam bidang hukum, sosial, politik, ekonomi, budaya, lingkungan hidup, serta pertahanan dan keamanan yang diselenggarakan dengan pembentukan peraturan-peraturan negara tak mungkin lagi terhindarkan".

Fokus peningkatan kesejahteraan masyarakat dapat dimulai dari tingkat desa, karena objek peningkatan kesejahteraan yang dimaksud adalah masyarakat yang belum atau kurang sejahtera, yang banyak mendiami desa-desa di Indonesia. Menurut data BPS Maret 2018, lebih dari 60\% total penduduk miskin Indonesia merupakan mereka yang hidup di pedesaan. Sehingga desa menjadi prioritas pembangunan pada pemerintahan saat ini, bukan hanya karena dominasi kemiskinan yang dimiliki oleh masyarakat desa, namun adanya sistem nilai yang telah hidup bersama masyarakat desa secara turun temurun, bahkan jauh sebelum negara Indonesia merdeka yang dibingkai menjadi otonomi asli desa.

Lahirnya UU No. 6 Tahun 2014 tentang Desa telah menjawab kebutuhan eksistensi desa dan desa adat dengan asas rekognisinya yang mengakui hak bawaan atau hak asal-usul secara utuh. Undang-Undang ini menggunakan fungsi Self Government, sehingga diharapkan kesatuan masyarakat hukum adat yang selama ini merupakan bagian dari wilayah desa, ditata sedemikian rupa menjadi desa dan desa adat.
Titik berat kesuksesan UU No. 6 Tahun 2014 tentang Desa melalui asas rekognisinya terkait pengakuan hak asal usul desa, didukung oleh peran pemerintah daerah baik pemerintah provinsi maupun pemerintah kabupaten/kota dalam hal penataan desa dan desa adat, seperti yang tertuang dalam Pasal 101 ayat (1) UU No. 6 Tahun 2014, yaitu: "Pemerintah, Pemerintah Daerah Provinsi, dan Pemerintah Daerah Kabupaten/Kota dapat melakukan penataan desa adat". Lebih lanjut pada ayat (2) menyebutkan: "Penataan Desa Adat sebagaimana dimaksud pada ayat (1) ditetapkan dalam peraturan daerah".

Di Provinsi Maluku, pengakuan terhadap kesatuan masyarakat adat telah dilakukan sebelum berlakunya undang-undang desa tahun 2014. Dengan berdasar pada UU No. 32 Tahun 2004 tentang Pemerintah Daerah dan PP No. 72 Tahun 2005 tentang Desa, Provinsi Maluku pada 2005 telah menerbitkan Perda Provinsi Maluku No. 14 Tahun 2005 tentang Penetapan Kembali Negeri Sebagai Kesatuan Masyarakat Hukum Adat Dalam Wilayah Pemerintahan Provinsi Maluku. Hal ini tidak terlepas dari persekutuan masyarakat hukum adat di Provinsi Maluku yang sejak dahulu eksistensinya sangat berpengaruh dalam berbagai aspek kehidupan, baik pemerintahan, ekonomi, pengelolaan dan pengendalian sumber daya alam dan sebagainya.

Namun dengan diberlakukannya Perda Provinsi Maluku No. 14 Tahun 2005 tersebut tidak serta merta mengembalikan sistem pemerintahan desa adat di maluku setelah diseragamkan bentuk maupun fungsinya, hal ini dikarenakan Pemerintah Provinsi Maluku tidak membuat aturan lebih lanjut terkait dengan kedudukan dan fungsi maupun kewenangan Negeri di Provinsi Maluku, dan diperparah oleh pemerintah kabupaten, khususnya Kabupaten Seram Bagian Barat yang tidak melakukan penetapan persekutuan masyarakat hukum adat sebagai Negeri di Kabupaten Seram Bagian Barat sebagaimana diamanatkan pada Pasal 7 ayat 
(1) Perda Provinsi Maluku No. 14 Tahun 2005, yaitu: "selambat lambatnya enam bulan setelah berlakunya Peraturan Daerah ini Bupati dan Wali kota pada Kabupaten dan Kota dalam wilayah Provinsi Maluku dengan persetujuan Dewan Perwakilan Rakyat Daerah Kabupaten/Kota wajib menyampaikan persekutuan masyarakat hukum adat di dalam wilayahnya sebagai Negeri yang selanjutnya akan ditetapkan dengan Keputusan Gubernur".

Semenjak berlakunya Perda Provinsi Maluku No. 14 Tahun 2005 dan berlakunya Undang Undang Desa 2014, hingga 2017 Pemerintah Daerah Kabupaten Seram Bagian Barat belum pernah mengeluarkan peraturan terkait dengan pengakuan Negeri maupun pengaturan sistem penyelenggaraan pemerintahan Negeri. Hal ini mendapat tanggapan serius dari masyarakat adat Seram Bagian Barat maupun akademisi, seperti dimuat dalam media online Mollucas Times dalam laman http://www.mollucastimes. com/2016/11/sisinaru-desak-dprd-sbbsegera-bentuk.html?m=1 (29 November 2016):

"Stones Sisinaru, Akademisi Fakultas Hukum Universitas Pattimura Ambon sekaligus anak daerah Saka Mese Nusa mendesak Dewan Perwakilan Rakyat Daerah (DPRD) Kabupaten Seram Bagian Barat (SBB) secepatnya membuat peraturan daerah yang mengatur mengenai negeri adat untuk menjawab kebutuhan masyarakat di SBB. Sebagai contoh di Kabupaten Maluku Tengah ada Perda No. 1 Tahun 2006 yang berbicara mengenai pemerintahan negeri, itu berarti mereka sudah mengatakan bahwa ini negeri adat,

Dikatakannya, Saka Mese Nusa terdapat banyak negeri adat. Namun fakta saat ini tidak terjawab karena regulasi daerah belum mengatur mengenai hal tersebut, sehingga banyak negeri-negeri adat masih dipimpin oleh karateker".
Melihat polemik yang terjadi di masyarakat Kabupaten Seram Bagian Barat terkait dengan status dan penyelenggaraan Pemerintahan Negeri, Pemerintah Kabupaten Seram Bagian Barat melalui DPRD Kabupaten Seram Bagian Barat pada 2017 membuat Rancangan Peraturan Daerah (Raperda) Penetapan Desa Adat, Raperda Negeri dan Raperda Saniri Negeri yang berasal dari Inisiatif DPRD Kabupaten Seram Bagian Barat, walaupun sampai memasuki semester akhir di tahun 2018 ke tiga Raperda tersebut belum diparipurnakan menjadi Perda.

Kepala Bagian Humas Sekretariat DPRD Kabupaten Seram Bagian Barat menyampaikan dari ketiga raperda inisiatif DPRD yakni Raperda Negeri, Raperda Penetapan Negeri dan Raperda Saniri Negeri, pada proses pembahasannya Raperda Negeri dan Raperda Saniri Negeri tidak banyak mengalami pertentangan, sehingga prosesnya mulai dari internal DPRD Kabupaten Seram Bagian Barat, pembahasan dengan unsur Pemerintah Daerah Kabupaten Seram Bagian Barat, sampai pembahasan dengan Pemerintah Provinsi Maluku sudah dilakukan dan berjalan dengan baik, hanya saja semenjak pertemuan terakhir bersama Pemerintah Daerah Kabupaten Seram Bagian Barat dan Pemerintah Provinsi Maluku, belum ada tindak lanjut terkait dengan kedua Raperda tersebut.

Raperda Penetapan Negeri masih belum dapat diproses lebih lanjut, karena terjadi penolakan di masyarakat yang berujung pada aksi demo kelompok-kelompok masyarakat yang menolak penetapan raperda tersebut. Sehingga berdasarkan hasil pembahasan dengan unsur Pemerintah Daerah Kabupaten Seram Bagian Barat disepakati bahwa terkait dengan Raperda Penetapan Negeri menunggu hasil kajian dari Pemerintah Daerah.

Raperda Penetapan Negeri merupakan penentuan terhadap desa mana yang 
ditetapkan menjadi desa adat atau Negeri dan desa mana yang bukan desa adat dari 92 desa yang berada di kabupaten Seram Bagian Barat. Di dalam Raperda Penetapan Negeri Pasal 5 disebutkan jumlah desa yang ditetapkan sebagai desa adat atau Negeri berjumlah 81 dari 92 desa di Kabupaten Seram Bagian Barat.

Berdasarkan data dari Sekretariat DPRD Kabupaten Seram Bagian Barat bahwa telah dilakukan tujuh kali rapat internal DPRD Kabupaten Seram Bagian Barat dalam penyusunan Raperda Desa Adat di Kabupaten Seram Bagian Barat, rapat pertama dimulai pada 11 Juli 2017 dengan agenda persiapan pembahasan Raperda Inisiatif DPRD Kabupaten Seram Bagian Barat yang dilakukan di internal Banleg, rapat kedua pada 26 Juli 2017 dengan agenda persiapan pembahasan raperda inisiatif DPRD Kabupaten Seram bagian Barat antara Banleg dengan Pimpinan DPRD, rapat ketiga pada 20 Desember 2017 dengan agenda koordinasi dengan Yayasan Payung Teduh terkait pembahasan raperda inisiatif DPRD Kabupaten Seram Bagian Barat, rapat keempat pada 5 Maret 2018 dan rapat kelima pada 9 April 2018 dengan agenda pembahasan raperda inisiatif DPRD Kabupaten Seram Bagian Barat di internal Banleg, rapat keenam pada 4 Juni 2018 dengan agenda persiapan pembahasan hasil fasilitasi dengan pemerintah daerah kabupaten seram bagian barat, rapat ketujuh pada 21 Juli 2018 dengan agenda tindak lanjut hasil evaluasi Biro Hukum Setda Provinsi Maluku terkait raperda inisiatif DPRD Kabupaten Seram Bagian Barat, dari ketujuh rapat internal DPRD tingkat kehadiran peserta rapat kurang dari 70\%.

Berdasarkan hasil wawancara awal penulis dengan Bapak Jems Kapuate selaku Kepala Bagian Pemerintahan Setda Kabupaten Seram Bagian Barat, beliau menyampaikan, telah dilaksanakan empat kali rapat antara DPRD Kabupaten Seram Bagian Barat dengan Unsur Pemerintah
Daerah Kabupaten Seram Bagian Barat, seperti Bagian Pemerintahan, Bagian Hukum, Badan Pemberdayaan Masyarakat dan Pemerintahan Desa, serta Sekretaris Daerah. dan satu kali rapat bersama Pemerintah Provinsi Maluku dalam pembahasan penyusunan maupun penetapan raperda inisiatif dari DPRD Kabupaten Seram Bagian Barat terkait desa adat di Kabupaten Seram Bagian Barat.

Rapat pertama pada November 2017 yang mengkaji nilai-nilai adat yang dapat di pakai dan kriteria unsur-unsur adat yang dapat diadopsi menjadi nilai adat dalam rumusan kebijakan, rapat kedua pada November 2017 yang mengkaji adat Tiga Batang Air yakni Batang Air Tala, Batang Air Eti dan Batang Air Sapalewa untuk dijadikan alternatif penetapan desa adat di Kabupaten Seram Bagian Barat, rapat ketiga pada April 2018, yaitu hearing antara DPRD dan Pemda Kabupaten Seram Bagian Barat untuk mempertajam muatan raperda tentang adat, rapat keempat pada Mei 2018 membahas penetapan negeri yang harus diidentifikasi oleh Pemerintah Daerah Kabupaten Seram Bagian Barat sehingga pembahasan Perda Penetapan Negeri menunggu proses identifikasi dari Pemda Kabupaten Seram Bagian Barat.

Rapat dengan Pemprov Maluku pada Juni 2018 untuk memastikan muatan raperda tidak bertentangan dengan peraturan yang lebih tinggi, dan lokakarya terkait nilai-nilai adat yang terkandung dalam raperda. Kepala Bagian Pemerintahan Kabupaten Seram Bagian Barat juga menyampaikan bahwa setelah proses rapat yang dilaksanakan di tingkat Provinsi Maluku dan sampai saat ini belum ada pembahasan lebih lanjut terkait kelanjutan proses raperda tersebut.

Rancangan peraturan daerah inisiatif DPRD Kabupaten Seram Bagian Barat juga telah dilakukan uji publik oleh Banleg yang dilaksanakan pada tiga wilayah kecamatan di Kabupaten Seram Bagian Barat. 
Berdasarkan uraian tersebut maka dapat dirumuskan masalah sebagai berikut: (1) Bagaimana proses pembentukan peraturan daerah mengenai desa adat di Kabupaten Seram Bagian Barat? (2) Apa faktor-faktor yang memengaruhi proses pembentukan peraturan daerah mengenai desa adat di Kabupaten Seram Bagian Barat? (3) Bagaimana strategi untuk mengefektifkan proses pembentukan peraturan daerah mengenai desa adat di Kabupaten Seram Bagian Barat?

Tujuan dari penelitian ini adalah sebagai berikut.

1. Untukmenganalisisprosespembentukan peraturan daerah mengenai desa adat di Kabupaten Seram Bagian Barat.

2. Untuk menganalisis faktor-faktor yang memengaruhi proses pembentukan peraturan daerah mengenai desa adat di Kabupaten Seram Bagian Barat.

3. Untuk menganalisis Strategi dalam mengefektifkan pembentukan peraturan daerah mengenai desa adat di Kabupaten Seram Bagian Barat.

Diharapkan dengan penelitian ini dapat memberikan manfaat secara teoretis, yaitu hasil penelitian ini dapat bermanfaat dalam pengembangan ilmu administrasi pemerintahan daerah khususnya dalam penyusunan peraturan daerah. dan secara praktis penelitian ini: (1) dapat menjadi sarana ilmiah mahasiswa dalam menambah pengetahuan dan pengalaman peneliti sebagai bekal dalam melaksanakan tugastugas sebagai aparatur pemerintah, (2) Dapat digunakan sebagai bahan masukan atau referensi Pemerintah Kabupaten Seram Bagian Barat dalam mengefektifkan proses pembentukan peraturan daerah, (3) Dapat dijadikan sebagai acuan dalam penelitian yang terkait dengan proses pembentukan peraturan daerah mengenai desa adat.

\section{KAJIAN PUSTAKA}

\section{Konsep Pemerintah Daerah}

Pemerintah adalah organisasi yang memiliki hak untuk melaksanakan kewenangan berdaulat atau tertinggi. Pemerintah dalam arti luas merupakan sesuatu yang lebih besar dari pada suatu kementerian yang diberi tanggung jawab memelihara perdamaian dan keamanan negara. Dapat dikatakan pula pemerintah adalah kekuasaan memerintah sesuatu negara (daerah negara) atau suatu badan atau lembaga yang tertinggi memerintah dalam suatu negara. Hal ini dibedakan dengan istilah pemerintah sebagai suatu perbuatan (cara, hal, urusan dan sebagainya). Memerintah secara etimologis dapat pula diartikan merupakan tindakan yang terus menerus atau suatu kebijakan yang menggunakan rencana maupun akal dengan cara tertentu, untuk mencapai suatu tinjauan tertentu yang dikehendaki.

Menurut Hamdi (2015: 15) pemerintah adalah "suatu gejala yang selalu hadir dalam kehidupan manusia. Setiap kali manusia berhasrat untuk hidup dalam suatu kelompok, maka gejala pemerintahan hadir dalam kehidupan mereka". Selanjutnya menurut Bevir dalam Wasistiono (2015: 87) membagi pemerintahan ke dalam dua pengertian sebagai berikut.

"The term government comes from greek word "kubernan", which means steering a ship. Memosisikan pemerintahan ibarat kemudi kapal (Istilah Yunani: Kubernan), mendorong Bevir membagi pengertian pemerintahan ke dalam dua pengertian yang dalam arti sempit sebagai sebuah istilah (government as an institution). Adapun dalam arti luas pemerintah diartikan sebagai sebuah proses (government as a process). Dalam konteks bahasa Indonesia, dibedakan antara pemerintah sebagai sebuah institusi atau orang yang memerintah, 
sedangkan pemerintahan diartikan sebagai sebuah proses atau aktivitas memerintah".

Definisi Pemerintahan Daerah berdasarkan Undang-undang No. 23 Tahun 2014 tentang Pemerintahan Daerah dalam Pasal 1 adalah sebagai berikut.

"Pemerintahan Daerah adalah penyelenggaraan urusan pemerintahan oleh pemerintah daerah dan dewan perwakilan rakyat daerah menurut asas otonomi dan tugas pembantuan dengan prinsip otonomi seluas-luasnya dalam sistem dan prinsip Negara Kesatuan Republik Indonesia sebagaimana dimaksud dalam Undang-Undang Dasar Republik Indonesia Tahun 1945. Adapun Pemerintah Daerah adalah kepala daerah sebagai unsur penyelenggara Pemerintahan Daerah yang memimpin pelaksanaan urusan pemerintahan yang menjadi kewenangan daerah otonom".

Definisi pemerintahan daerah di atas, maksudnya adalah bahwa pemerintahan daerah di sini adalah penyelenggaraan daerah otonom oleh pemerintah daerah dan DPRD menurut asas desentralisasi dan unsur penyelenggara pemerintah daerah adalah Gubernur, Bupati atau Wali kota dan perangkat daerah.

Menurut Gie (2000: 5) menjelaskan pengertian Pemerintah Daerah adalah "satuan-satuan organisasi pemerintah yang berwenang untuk menyelenggarakan segenap kepentingan setempat dari sekelompok yang mendiami suatu wilayah yang dipimpin oleh Kepala Pemerintah Daerah yang dipilih secara demokrasi". Adapun menurut Muttalib dan Akbar (2013: 2) mengemukakan pengertian Pemerintah Daerah sebagai berikut.

"Pemerintah Daerah adalah perpaduan antara dua aliran filosofis, yaitu "pemerintahan sendiri" dan pemerintahan yang baik. Pemerintahan sendiri merupakan sebuah keharusan, baik secara psikologis maupun pragmatis, artinya ada sekelompok orang yang hidup bersama mengalir secara alami dalam mewujudkan identitas dan ekspresi lokal serta demi efisiensi dan efektivitas pelaksanaan aktivitas pemerintah daerah".

Berdasarkan definisi di atas, dapat disimpulkan Pemerintah Daerah adalah suatu proses kegiatan penyelenggaraan pemerintahan di daerah, yaitu sebagai pelaksana semua kegiatan yang mengatur jalannya pemerintahan yang ada di daerah berdasarkan tugas dan fungsi pemerintah daerah.

\section{Proses Pembentukan Peraturan Daerah}

Hamid S. Attamimi dalam bukunya yang berjudul Hukum tentang peraturan perundang dan peraturan kebijakan (hukum tata negara) sebagaimana dikutip oleh Halim (2013: 17) menyebutkan bahwa suatu pembentukan peraturan perundangundangan yang baik harus memenuhi asasasas pembentukan peraturan yang baik terdiri dari asas formal dan material sebagai berikut.

1. Asas-asas formal dengan rincian:

a. Asas tujuan yang jelas;

b. Asas perlunya anggaran;

c. Asas organ/lembaga yang tepat;

d. Asas materi muatan yang tepat;

e. Asas dapatnya dilaksanakan; dan

f. Asas dapatnya dikenali.

2. Asas-asas material dengan rincian:

a. Asas sesuai dengan cita hukum Indonesia dan norma fundamental negara;

b. Asas sesuai dengan hukum dasar negara;

c. Asas sesuai dengan prinsip-prinsip negara berdasar atas hukum; dan

d. Asas sesuai dengan prinsip-prinsip pemerintahan berdasar sistem konstitusi. 
Berdasarkan Undang-Undang No. 12 Tahun 2011 tentang Pembentukan Peraturan Perundang-undangan Pasal 7 menyebutkan bahwa jenis dan hierarki Peraturan Perundang-undangan terdiri atas :

1. Undang-Undang Dasar Negara Republik Indonesia Tahun 1945;

2. Ketetapan Majelis Permusyawaratan Rakyat;

3. Undang-Undang/Peraturan Pemerintah Pengganti Undang-Undang;

4. Peraturan Pemerintah;

5. Peraturan Presiden;

6. Peraturan Daerah Provinsi; dan

7. Peraturan Daerah Kabupaten/Kota".

Proses atau tata cara pembentukan suatu peraturan perundang-undangan daerah menurut Indrati (2017: 44) menjelaskan :

"Dari berbagai tahapan dalam pembentukan Undang-Undang, dan berbagai peraturan yang menjadi landasan dan pedoman dalam proses pembentukannya, dapat dikemukakan bahwa pembentukan Undang-Undang terdiri dari tahap 1) Tahap Perencanaan; 2) Tahap Penyiapan; 3) Tahap Pembahasan; 4) Tahap Pengesahan; dan 5) Tahap Pengundangan".

Halim (2013: 98) juga mengemukakan "untuk memperoleh sebuah produk hukum yang berkualitas, maka di dalam proses pembentukannya harus dilakukan melalui proses penahapan yang terdiri dari tahap perencanaan, tahap perancangan, tahap pembahasan, tahap pengundangan, tahap sosialisasi, dan tahap Evaluasi".

Dalam penelitian proses pembentukan peraturan daerah mengenai desa adat penulis menggunakan teori Indrati (2017) dikarenakan teori indrati membahas proses pembentukan peraturan daerah dari tahap awal dibentuk sampai peraturan daerah tersebut jadi atau diundangkan, kemudian membahas dimensi pembahasan pada teori Indrati menggunakan pendapat Halim (2013:
50), yaitu pada tahap Pembahasan, Raperda dibahas oleh DPRD dengan Gubernur, bupati/ wali kota untuk mendapatkan persetujuan bersama. Pembahasan sebuah Raperda di DPRD dilakukan di dalam 4 (empat tingkat pembicaraan) masing-masing dengan agenda tersendiri sebagai berikut.

a) Pembicaraan Tingkat I agendanya adalah penyampaian keterangan/ penjelasan DPRD atas Raperda.

b) Pembicaraan Tingkat II agendanya adalah tanggapan kepala daerah atas Raperda yang berasal dari DPRD dan jawaban DPRD atas tanggapan kepala daerah.

c) Pembicaraan Tingkat III agendanya adalah pembahasan Raperda dalam komisi, atau gabungan komisi, atau oleh panitia khusus bersama dengan kepala daerah dan pembahasan Raperda secara intern di dalam komisi, atau gabungan komisi, atau panitia khusus.

d) Pembicaraan Tingkat IV agendanya laporan hasil pembahasan raperda pada pembicaraan tingkat III, pandangan akhir fraksi, dan pengambilan keputusan oleh DPRD

\section{Faktor-Faktor yang Memengaruhi Pembentukan Peraturan Daerah}

Faktor-Faktor yang memengaruhi pembentukan peraturan daerah seperti yang dikemukakan oleh Halim (2009: 6-7) terdiri atas:

\section{Legislation Function}

DPR dan DPRD saat ini tidak lagi bisa disamakan dengan DPR dan DPRD pada masa lalu yang kurang berperan dalam melaksanakan fungsi legislasinya. DPR dan DPRD saat ini bisa memainkan peran check and balances dengan lebih efektif dari setiap kebijakan yang ditempuh oleh pemerintah melalui kinerja fungsi dewan, khususnya fungsi legislasi. Namun harus disadari bahwa 
setiap DPR dan DPRD tidak akan mampu mencapai kinerja yang efisien dan efektif tanpa adanya dukungan yang memadai dari profesional dan supporting system yang ada. Terkait dengan fungsi legislasi, dewan saat ini mendapat sorotan yang tajam dari berbagai pihak, baik itu kaitannya dengan tingkat produktivitasnya (produk legislasinya) maupun menyangkut kualitas dari produk legislasi yang dihasilkannya, termasuk kaitannya dengan pelibatan partisipasi masyarakat di dalam suatu proses penyusunan dan perancangan suatu perda.

\section{Legal Drafters}

Kesulitan di dalam penyusunan suatu perda sering kali muncul sebagai akibat kurangnya perhatian dan pemahaman para perancang untuk memperdalam pengetahuan aturan hukum dan situasi yang sedang berkembang di dalam masyarakat. di dalam merumuskan penyusunan program legislasi yang efektif, para perancang perlu memahami beberapa faktor, seperti kewenangan, landasan, syarat dan prinsip, serta fungsi dan materi muatan peraturan yang disusun. Faktor-faktor ini pada dasarnya merupakan patokan untuk membuat perancangan program legislasi secara tepat dan berstandar. Dengan demikian, diperlukan peran dan kontribusi tenaga perancang sebagai tenaga fungsional yang berkualitas yang mempunyai tugas menyiapkan, mengolah, dan merumuskan suatu perda.

\section{Dinamika Masyarakat}

Pembentukan peraturan perundangundangan termasuk perda merupakan suatu proses yang dinamis yang terus menerus mengalami perubahan sesuai dengan dinamika masyarakat. Dinamika tersebut berubah semakin cepat di era globalisasi dewasa ini yang dipicu oleh kemajuan teknologi informasi yang menjadikan dunia sebagai suatu kesatuan global. Oleh karena itu, idealnya upaya pembentukan suatu peraturan daerah secara komprehensif paling tidak harus memperhatikan tiga dimensi utama, yaitu masa lalu yang terkait dengan eksistensi daerah itu, masa kini, yaitu kondisi objektif yang ada sekarang dengan lingkungan strategisnya dan dengan memandang ke masa depan yang dicita-citakan.

\section{METODE PENELITIAN}

Penelitian ini merupakan penelitian yang menggunakan pendekatan kualitatif dengan metode deskriptif di mana teknik pengumpulan data dengan menggunakan teknik wawancara, dokumentasi, dan observasi. Teknis analisis data menggunakan interactive model oleh Miles and Huberman. Teknik penentuan informan menggunakan purposive sampling dan snowball sampling.

\section{SIMPULAN DAN SARAN}

\section{SimpUlan}

Berdasarkan hasil penelitian yang dilakukan tentang proses pembentukan peraturan daerah mengenai desa adat di Kabupaten Seram Bagian Barat Provinsi Maluku, maka peneliti dapat menarik simpulan dalam penelitian ini adalah sebagai berikut.

Pertama, proses pembentukan peraturan daerah mengenai desa adat di Kabupaten Seram Bagian Barat belum dilaksanakan sesuai dengan teori dan ketentuan peraturan perundang-undangan, yang mengakibatkan rancangan peraturan daerah mengenai desa adat di Kabupaten Seram Bagian Barat belum dapat ditetapkan dan disahkan menjadi peraturan daerah. Hal ini dapat dijelaskan sebagai berikut.

\section{a. Perencanaan}

Proses pembentukan peraturan daerah mengenai desa adat di Kabupaten 
Seram Bagian Barat dilaksanakan tidak melalui perencanaan dalam Program Pembentukan Peraturan Daerah.

b. Penyiapan

Proses penyiapan rancangan peraturan daerah mengenai desa adat di Kabupaten Seram Bagian Barat sudah sesuai mekanisme dengan membuat naskah akademik kemudian dilakukan dikonsepsi menjadi Raperda DPRD dan menetapkannya menjadi Raperda Inisiatif DPRD.

\section{c. Pembahasan}

Tahap pembahasan dilaksanakan hanya sampai pada Pembicaraan Tingkat III. Hal ini dikarenakan adanya perbedaan pandangan antara DPRD dan pemerintah daerah Kabupaten Seram Bagian Barat, di mana dalam pembahasan ketiga Raperda mengenai desa adat, DPRD meminta Pemerintah Daerah Kabupaten Seram Bagian Barat untuk segera menyiapkan Keputusan Bupati tentang Penetapan Negeri, sebagai syarat pembentukan Raperda tentang Penetapan Negeri, sehingga Raperda Penetapan Negeri bisa ditetapkan bersama dengan Raperda Negeri dan Raperda Saniri Negeri. Berbeda dengan Pemerintah Daerah Kabupaten Seram Bagian Barat, yang meminta untuk ditetapkan dulu Raperda Negeri dan Raperda Saniri Negeri, sehingga menjadi dasar hukum dalam pembentukan Raperda tentang Penetapan Negeri.

d. Pengesahan

Tahap pengesahan belum dilaksanakan oleh Bupati Seram Bagian Barat dikarenakan belum dilaksanakannya sidang paripurna penetapan peraturan daerah mengenai desa adat.

e. Pengundangan

Tahap pengundangan dalam lembar daerah belum dilaksanakan oleh Sekretaris Daerah Kabupaten Seram
Bagian Barat dikarenakan Raperda desa adat belum disahkan.

Kedua, proses pembentukan peraturan daerah mengenai desa adat di Kabupaten Seram Bagian Barat dipengaruhi oleh faktor-faktor yang meliputi, masih kurangnya kualitas anggota DPRD Kabupaten Seram Bagian Barat dalam memahami tugas dan fungsinya selaku inisiator pembentukan peraturan daerah, adanya kepentingan dari berbagai pihak di internal DPRD Kabupaten Seram Bagian Barat dalam merumuskan rancangan peraturan daerah mengenai desa adat, masih kurangnya kualitas SDM dari tenaga perancang, yaitu staf sekretariat DPRD Kabupaten Seram bagian Barat dan pihak ketiga Lembaga Payung Teduh dalam membantu merumuskan rancangan peraturan daerah mengenai desa adat, kelambatannya penetapan desa adat oleh pemerintah daerah, dan kurangnya pelibatan partisipasi masyarakat khususnya Dewan Adat di Kabupaten Seram Bagian Barat dalam penyusunan peraturan daerah mengenai desa adat di Kabupaten Seram Bagian Barat.

Ketiga, strategi untuk mengefektifkan pembentukan peraturan daerah mengenai desa adat di Kabupaten Seram Bagian Barat dianalisis menggunakan SWOT dengan pengujian Litmus Test akan menjadi saran dalam penelitian ini.

\section{SARAN}

Agar proses pembentukan peraturan daerah mengenai desa adat di Kabupaten Seram Bagian Barat dapat berjalan dengan efektif maka saran yang diberikan adalah:

1. Membangun komunikasi yang baik antara DPRD dengan Pemerintah Daerah dalam penyelesaian Raperda mengenai desa adat sesuai dengan mekanisme yang diamanatkan Undang-Undang No. 6 Tahun 2014 tentang Desa, Peraturan Pemerintah No. 43 Tahun 2014 tentang Peraturan Pelaksanaan Undang-Undang No. 6 Tahun 2014 tentang Desa dan 
Permendagri No. 1 Tahun 2017 tentang Penataan Desa, di mana Pemerintah Daerah Kabupaten Seram Bagian Barat yang berwenang melakukan identifikasi desa dan desa adat. Sehingga penyelesaian Raperda Penetapan Negeri dapat segera terlaksana.

2. Melibatkan partisipasi masyarakat khususnya Dewan adat Saniri Tiga Batang Air dalam penyusunan rancangan peraturan daerah, di mana Dewan Adat Saniri Tiga Batang Air merupakan lembaga adat tertinggi di Kabupaten Seram Bagian Barat, yang lebih memahami latar belakang adat istiadat dan penyelenggaraan pemerintahan desa adat di Kabupaten Seram Bagian Barat. dan memperbanyak sosialisasi kepada masyarakat sehingga masyarakat tau perkembangan pembentukan raperda mengenai desa adat.

3. Meminimalisir kepentingan yang bertentangan dengan aturan normatif dan aturan adat di Kabupaten Seram Bagian Barat sehingga proses pembentukan perda desa adat dapat cepat terselesaikan.

4. Mengupayakan proses pemilihan kepala desa atau Raja Negeri tanpa menunggu ditetapkannya perda mengenai desa adat demi menjaga kualitas penyusunan Raperda mengenai desa adat.

\section{DAFTAR PUSTAKA}

Bryson, John, M, 2016, Perencanaan Strategis Bagi Organisasi Sosial. Pustaka Pelajar, Yogyakarta

Creswell, John W, 2009, Research Design Pendekatan Metode Kualitatif Kuantitatif dan Campuran, Pustaka Pelajar, Yogyakarta.

Direktorat Jenderal Peraturan Perundangundangan Kementerian Hukum dan Hak Asasi Manusia RI, 2011, Panduan Praktis Memahami Perancangan Peraturan
Daerah, Direktorat Jenderal Peraturan Perundang-undangan, Jakarta.

Gie, The Liang, 2000, Administrasi Perkantoran, Modern Liberty, Yogyakarta.

Halim, Hamzah, 2013, Cara Praktis Menyusun dan Merancang Peraturan Daerah (Suatu Kajian Teoretis dan Praktis Disertai Manual) Konsepsi Teoretis Menuju Artikulasi Empiris, Prenadamedia Group, Jakarta.

Hamdi, Muchlis, 2015, Kebijakan Publik: Proses, Analisis, dan Partisipasi, Ghalia Indonesia, Bogor.

Indrati, Maria Farida, 2017, Ilmu Perundangundangan: Proses dan Teknik Pembentukannya, Kanisius, Jakarta.

Indrati, Maria Farida, 2017, Ilmu Perundangundangan: Jenis, Fungsi, dan Materi Muatan, Kanisius, Jakarta.

Rangkuti, Freddy. 2016, Teknik Membedah Kasus Bisnis Analisis SWOT, Gramedia Pustaka Utama. Jakarta.

\section{Peraturan Perundang-Undangan}

Undang Undang Dasar Negara Republik Indonesia Tahun 1945

Undang-Undang No. 12 Tahun 2011 tentang Pembentukan Peraturan Perundangundangan

Undang-Undang No. 6 Tahun 2014 tentang Desa

Undang-Undang No. 23 Tahun 2014 tentang Pemerintahan Daerah

Perda Provinsi Maluku No 14. Tahun 2005 tentang Penetapan Kembali Negeri Sebagai Kesatuan Masyarakat Hukum Adat Dalam Wilayah Pemerintahan Provinsi Maluku

Peraturan DPRD Kabupaten Seram Bagian Barat No. 1 Tahun 2017 tentang Tata Tertib DPRD Kabupaten Seram Bagian Barat

\section{Sumber Lain}

Naskah Akademik Raperda Kabupaten Seram Bagian Barat tentang Negeri

Naskah Akademik Raperda Kabupaten Seram Bagian Barat tentang Penetapan Negeri 
Naskah Akademik Raperda Kabupaten Seram Bagian Barat tentang Saniri Negeri

Badan Pusat Statistik, (2018, 16 Juli) Persentase Penduduk Miskin Maret 2018. BPS [online], Tersedia: https://www.bps. go.id. [15 November 2018]
Mollucas Times, (2016, November) Sisinaru Desak DPRD SBB Segera Bentuk Perda Negeri Adat. Mollucastimes.com [online], Tersedia: http://www.mollucastimes. com/2016/11/sisinaru-desak-dprd-sbbsegera-bentuk.html?m=1. [15 November 2018 